\title{
Autoimmune encephalitis with psychiatric features in adults: historical evolution and prospective challenge
}

\author{
Niels Hansen ${ }^{1}$. Charles Timäus ${ }^{1}$ \\ Received: 13 August 2020 / Accepted: 22 September 2020 / Published online: 7 October 2020 \\ (c) The Author(s) 2020
}

\begin{abstract}
Our review aims to delineate the psychiatric spectrum of autoantibody-associated autoimmune encephalitis over time through its discoveries of antibodies. We searched in PubMed for appropriate articles depicting the first appearance and spectrum of psychiatric symptomatology in autoantibody-positive encephalitis for this narrative review. Memory impairment was first associated with autoantibodies against intracellular antigens such as anti-HuD antibodies in 1993. 8 years later, autoantibodies against cell membrane surface antigens such as voltage-gated potassium channels were described in conjunction with memory dysfunction. The spectrum of psychiatric syndromes was amplified between 1990 and 2020 to include disorientation, behavior, cognitive dysfunction, obsessive compulsive behavior and suicidality in encephalitis patients occurring together mainly with antibodies against surface antigens, less so against intracellular antigens. In general, we found no specific psychiatric symptoms underlying specific autoantibody-associated encephalitis. As fundamental data on this issue have not been systemically assessed to date, we cannot know whether our specific findings would remain from systematic studies, i.e., on the association between cerebrospinal fluid N-methyl-D-aspartate receptor antibodies in catatonia. The psychiatric symptomatology overlaps between psychiatric domains and occurs frequently in antibody-positive encephalitis. No specific psychiatric symptoms imply an underlying, specifically autoantibody-associated encephalitis. The psychiatric phenotypology associated with antibody-positive encephalitis has evolved tremendously recently, and this new evidence reveals its relevance for future diagnostic and treatment aspects of autoimmune encephalitis patients.
\end{abstract}

Keywords Autoimmune encephalitis $\cdot$ Psychiatry $\cdot$ Autoantibodies $\cdot$ Intracellular antibodies $\cdot$ Membrane surface antibodies

\section{Introduction}

Autoimmune encephalitis is a disorder that can dynamically alter its phenotypical appearance over time. It is often characterized by an initial psychiatric manifestation, or reveals predominant or isolated psychiatric features (Kayser et al. 2013; Herken and Prüss 2017). The aim of this review is to depict the historic evolution of the published psychiatric phenomenology of autoimmune encephalitis.

Niels Hansen

niels.hansen@med.uni-goettingen.de

1 Department of Psychiatry and Psychotherapy, University of Goettingen, Von-Siebold-Str. 5, 37075 Goettingen, Germany

\section{Methods}

We looked through the PubMed database for appropriate articles comprising the terms "autoimmune encephalitis AND psychiatry", "AK5 (adenylate kinase 5)/Amiphiphysin/AMPAR (a-amino-3-hydroxy-5-methyl-4isoxazolepropionic acid receptor)/ BRSK2 (BR serine/ threonine kinase 2)/CASPR2 (contactin-associated protein 2/CRMP3/4 (collapsing reponse mediator protein 3/4)/CV2/ CRMP5 (cronveinten 2/collapsing response mediator protein 5), debrin/ DPPX (dipeptidyl aminopeptidase-like protein 6), GABAAR (gammaaminobutyric acid protein A receptor)/ GABABR (gammaaminobutyric acid protein B receptor)/ GAD65 (glutamic acid decarboxylase 65)/GlycinR/HuD/ KLP11 (Kelch like 11 protein)/LGI1 (Leucine rich glioma inactivated protein 1)/Ma/Ta/mGluR5 (metabotropic glutamate receptor 5)/Neurexin3alpha/NMDAR (N-methyl-Daspartate receptor)/Ri, Ro, SOX1/Synapsin/VGKC (voltage gated potassium channel)/Zic4, AND psychiatry". 
We elucidate the autoantibodies' discoveries via their first psychiatric presentation. Our classification of psychiatric features relies on the analysis strategy of Al Diwani et al. (2019), categorizing psychiatric features into eight main domains entailing dysfunctional behavior, catatonia, eating or mood abnormalities, obsessive-compulsive behavior, psychosis, sleep dysfunction and suicidality.

\section{Results}

\section{First description of presumed paraneoplastic encephalitis with psychiatric features}

Neuroimmunological researchers suggest (Schulz and Prüss 2015) that paraneoplastic autoimmune encephalitis was first described over 130 years ago by the neurologist Oppenheim 1888 (Fig. 1). Oppenheim described a 54-year-old woman with neuropsychiatric symptomatology along with a prominent mood dysfunction in addition to other brain dysfunctions such as aphasia and agnosia. Her autopsy revealed gastric cancer, but no abnormalities were observed in brain tissue. Thus it was postulated that the tumor could be the cause of focal neurological symptoms. The presumption of carcinoma-induced neurological symptoms implies a possible autoimmune process induced by tumor immunity.

\section{First description of limbic encephalitis with psychiatric features}

About 80 years later, Brierley described three patients with limbic encephalitis comprising psychiatric features such as memory impairment, depressive syndrome, behavioral abnormalities and anxiety in addition to seizures and disturbed consciousness (Brierley et al. 1960) (Fig. 1). The notion limbic encephalitis was named nearly a decade later by Corsellis (Corsellis et al. 1968) (Fig. 1). Limbic encephalitis corresponds to an autoimmune encephalitis in the limbic system space. "Limbic syndrome" entails several specific clinical features such as memory impairment, seizures, and psychiatric abnormalities.

\section{Consensus criteria for autoimmune encephalitis including psychiatric features}

Nearly 50 years later, Graus et al. (2016) (Fig. 1) developed consensus criteria to define autoimmune encephalitis. Its definition is based on four criteria-all of which are necessary for this diagnosis. The four criteria are: (1) subacute onset of symptoms characterized by "working memory deficits, seizures, or psychiatric symptoms". The symptoms must reveal the tendency to accelerate over a timeline lasting under 3 months. Furthermore, either "working memory deficits, seizures, or psychiatric symptoms" together with limbic-system involvement must be present. In addition, (2) magnetic resonance imaging should depict brain abnormalities in both hemispheres within the medial temporal lobes on magnetic resonance imaging (MRI). Furthermore, (3) CSF should reveal pleocytosis or the EEG should show abnormal temporal activity as epileptic potentials or slowing. (4) Several alternative possible causes should be excluded.

In contrast, the clinician should assume a possible autoimmune encephalitis with psychiatric features according to Graus et al. (2016) if three criteria are met. The first criterion encompasses a subacute onset entailing changes in mental status and psychiatric symptoms, in addition to working memory deficits. The second criterion comprises one of the following: novel central focal neurological deficits, novel seizures, pleocytosis in CSF, or unilateral MRI temporal abnormalities. The third criterion is the absolute exclusion of any other possible causes. Two main subgroups of autoimmune encephalitis are distinguished according to their associated autoantibodies: those with autoantibodies (1) directed against membrane surface antigens and those (2) that target intracellular antigens. In our review, we employ the superordinate term autoimmune encephalitis, although most reports refer to a limbic encephalitis as a subform of autoimmune encephalitis-but the superordinate concept included also NMDAR encephalitis often not restricted to the limbic system.

\section{Differential diagnosis of autoimmune encephalitis with psychiatric features}

The differential diagnosis of autoimmune encephalitis is often demanding, and other diseases must be carefully ruled out in every patient. Several other disease entities need to be considered, such as the neuropsychiatric phenotype of lupus erythematosus often associated with double-stranded deoxyribonucleic acid antibodies, anti-antiphospholipid antibodies, anti-B2-glycoprotein-I, lupus anti-coagulant or anti-ribonucleoprotein antibodies (Nikolopoulos et al. 2020). Furthermore, Hashimoto encephalopathy in conjunction with psychiatric symptoms and thyroid autoimmunity must be excluded by thoroughly investigating the existence of antibodies against thyroid peroxidase (TPO) and thyroglobulin (TG) (Barbero et al. 2019; Barbuti et al. 2017). In children, it is important to screen for pediatric autoimmune neuropsychiatric disorder, which is associated with streptococcal infections (PANDAS) entailing a tic disorder together with preceding streptococcal infections revealing antibodies against streptococcal proteins, human brain enolase or neural tissue (Nicollini et al. 2015; Shimasaki et al. 2020). Another neuropsychiatric syndrome occurring in children and young adults is Rasmussen encephalitis: a 


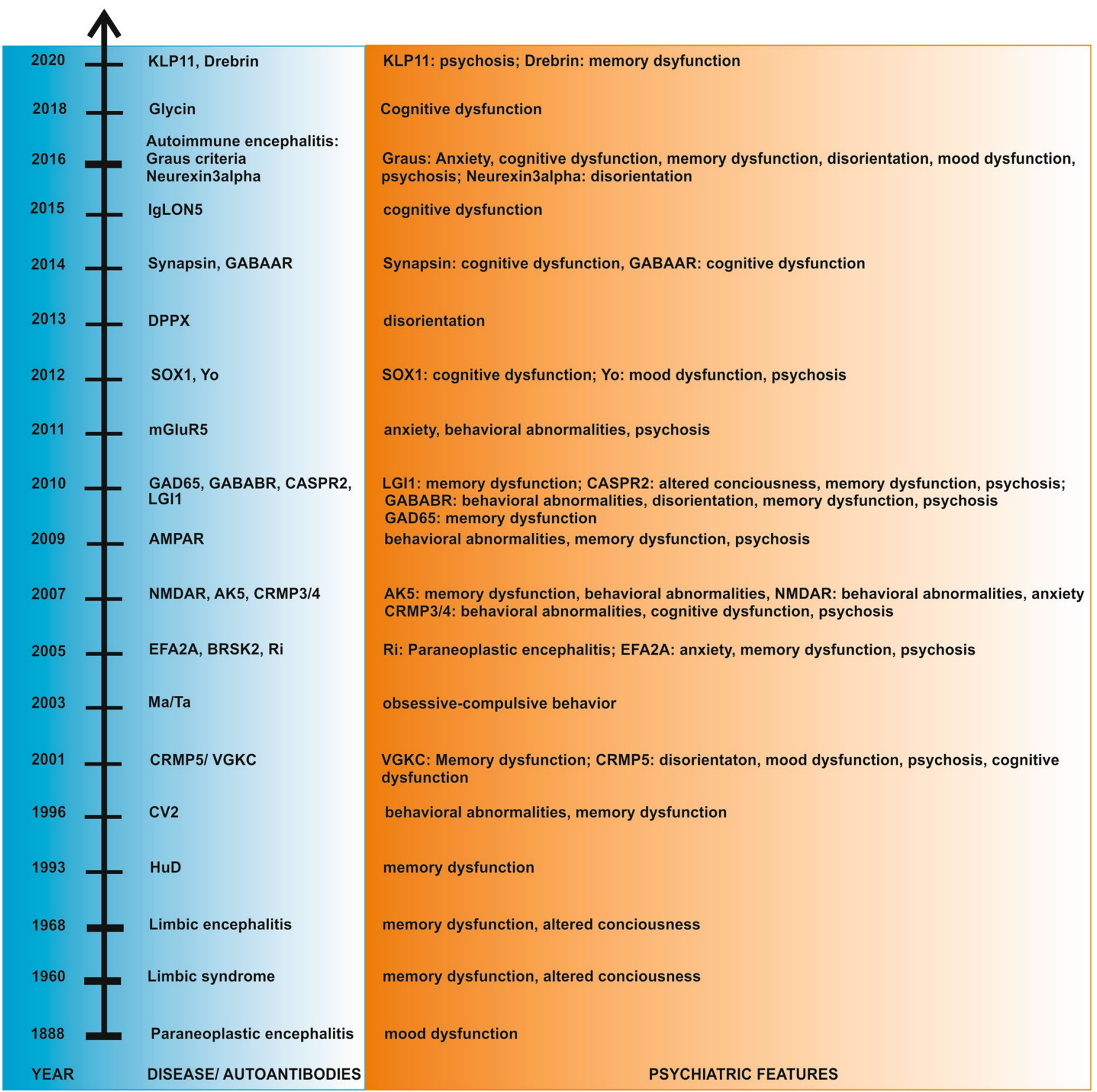

Fig. 1 Timeline of autoimmune encephalitis with psychiatric features. $A E-G C$ autoimmune encephalitis-Graus criteria, $A K 5$ adenylate kinase 5, AMPAR a-amino-3-hydroxy-5-methyl-4-isoxazolepropionic acid receptor, $B$ behavior, $B R S K 2$ BR serine/threonine kinase 2, $C A S P R 2$ contactin-associated protein 2, CRMP3/4 collapsing reponse mediator protein 3/ 4, CRMP5 collapsing response mediator protein 5, $C V 2$ cronveinten 2, DPPX dipeptidyl aminopeptidase-like protein

chronic neuroinflammation of one hemisphere along with drug-resistant seizures and severe cognitive dysfunction (Varadakar et al. 2014). These disease entities need to be
6, GABAAR gammaaminobutyric acid protein A receptor, $G A B A B R$ gammaaminobutyric acid protein B receptor, GAD65 glutamic acid decarboxylase $65, K L P 11$ Kelch like 11 protein, LGII Leucine-rich glioma-inactivated protein 1, mGluR5 metabotropic glutamate receptor 5, NMDAR $N$-methyl-D-aspartate receptor, $V G K C$ voltage-gated potassium channel

carefully excluded during the differential diagnosis before specifying the autoimmune encephalitis diagnosis. 


\section{Autoimmune encephalitis associated with antibodies against intracellular antigens}

Historically speaking, autoimmune encephalitis with antibodies against intracellular antigens was discovered before autoimmune encephalitis with antibodies against membrane surface antibodies. The first report of HuD-positive encephalitis described a memory impairment as a relevant neuropsychiatric appearance (Tsukamato et al. 1993) (see Fig. 1 for autoimmune encephalitis associated with specific autoantibodies and its first psychiatric presentation; see Table 1 for psychiatric syndromes associated with autoantibodies). $\mathrm{HuD}$ is an intracellular RNA-packed protein that is important for nervous system upgrowth and synaptic plasticity in the brain (Perrone-Bizzozero and Bird 2013). It is thus not surprising that autoantibodies against $\mathrm{HuD}$ affect synaptic transmission, thereby inducing memory impairment; however, the exact mechanism is unclear. Later, Graus confirmed in 2001 (Graus et al. 2001) that memory impairment is a cardinal feature of HuD-positive encephalitis. Two years later, other clinical psychiatric features were described such as topographical disorientation in a 70-year-old woman (Hirayama et al. 2003) (Fig. 1). In 1996, another paraneoplastic antibody against the intracellular antigen CV2 was identified in paraneoplastic neurological syndromes including encephalitis partly characterized by psychiatric features in 45 patients. Three of those patients had a limbic encephalitis presenting with catatonic behavior such as mutism and amnesia (Honnorat et al. 1996). The $66 \mathrm{kDa}$ peptide CV2/CRMP5 is often expressed in the thymus and within a thymoma (Camdessanché et al. 2006), indicating their impact on immunity and in regulating tumor immunity. In 2001-2002, cognitive impairment, disorientation, depressive and psychotic syndrome were reported as the clinically symptomatological complex of CRMP5-positive encephalitis (Yu et al. 2001; Vernino et al. 2002) (Fig. 1). Obsessive-compulsive behavior can also be a manifestation of this disease (Muehlschlaegel et al. 2005). Obsessive-compulsive behavior in association with $\mathrm{Ma}$ /Ta-positive encephalitis has also been identified (Scheid et al. 2003) (Fig. 1). A year later, Dalmau et al. (2004) reported a more variable clinical picture ranging from delirium to depressive syndrome in a larger cohort of 38 patients with Ma2-positive encephalitis. Four years later, personality changes, amnesia or behavioral symptoms such as lethargy were observed in 22 patients with $\mathrm{Ma} / \mathrm{Ta}$ paraneoplastic limbic encephalitis (Hoffmann et al. 2008). A man was reported in 2005 presenting with encephalitis due to serum Ri antibodies based on a lung carcinoma associated with personality changes and neuropsychological deficits (Harloff et al. 2005) (Fig. 1). Another novel autoantigen was discovered in 2005 (Fig. 1) by Sabater's group (Sabater et al. 2005), who diagnosed serum BR serine/threonine kinase 2 (BRK2) antibodies in a patient with a "limbic syndrome" in conjunction with lung cancer crucial for neuronal transmission and development. As there have been no further reports on this antibody, it must occur very seldom in autoimmune encephalitis patients. Two years later, serum and CSF adenylate kinase 5 antibodies were discovered in two men with autoimmune encephalitis associated with memory deficits, personality changes, and behavioral symptoms such as aggression and agitation (Tüzün et al. 2007) (Fig. 1). Their role in cellular homeostasis, and the particular expression of AK5 in the brain constitutes neuronal dysfunction within brain homeostasis if CSF AK5 antibodies are detected. Later reports of other psychiatric features were published, such as behavioral symptoms like disinhibition and memory loss ( $\mathrm{Ng}$ et al. 2015) including anterograde amnesia (Do et al. 2017; Bien et al. 2019), mood disturbances including a depressive syndrome (Do et al. 2017; Bien et al. 2019), and anxiety (Do et al. 2017). The specific pathophysiological relevance of cross-reactive antibodies is unclear. In patients with encephalitis and HuD antibodies as well as serum and CSF SOX1 antibodies (Fig. 1) were reported in a 59-yearold female suffering from cognitive impairment (Stich et al. 2012), recalling that the contribution of SOX1 antibodies to cognitive impairment remains unknown. A schizoaffective syndrome was reported in 2012 as being associated with low-titer serum and CSF paraneoplastic Yo antibodies directed against an intracellular $62 \mathrm{kDa}$ Purkinje cell protein (Fig. 1). Neuroimaging revealed no typical signs of encephalitis, but frontotemporal atrophy in MRI and cerebellar hypometabolism in FDG-PET were diagnosed (Endres et al. 2015). We suspect that a chronic neuroinflammation might have led to neurodegeneration culminating in frontotemporal atrophy. Novel serum Drebrin autoantibodies have been detected in patients with suspected limbic encephalitis, often accompanied by memory impairment (Pitsch et al. 2020) (Fig. 1). Drebrin, the postsynaptic protein located intracellularly, plays an important role in synaptic function and hippocampal excitability (Pitsch et al. 2020); therefore, the memory impairment we observe in these patients might result from disturbed synaptic neurotransmission and altered neuronal excitability in the hippocampus.

\section{Autoimmune encephalitis together with autoantibodies against membrane surface antigens}

Patients with autoimmune encephalitis associated with antibodies against membrane surface antigens are more often affected by psychiatric symptoms than are those with autoimmune encephalitis associated with autoantibodies against intracellular antigens (Fig. 1; Table 1). 


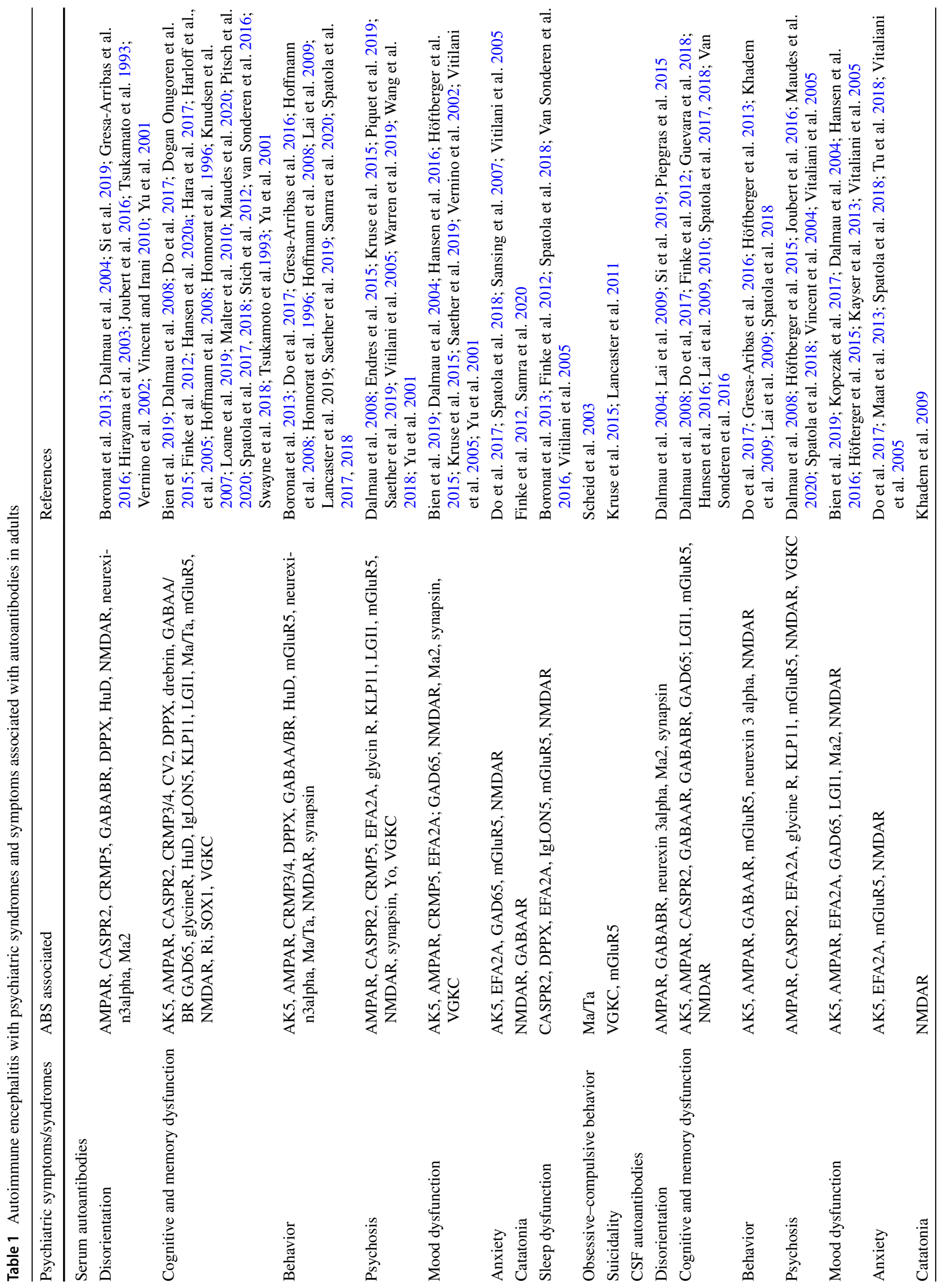


Limbic encephalitis associated with limbic mental symptoms such as memory disturbances have been already reported by Buckley (2001) in two patients presenting with positive serum VGKC antibodies (Fig. 1). Just 3 years later, the psychiatric spectrum was expanded to include behavioral abnormalities such as apathy, mood symptoms like irritability, and psychotic symptoms such as visual hallucinations reportedly associated with VGKC-positive encephalitis (Thieben et al. 2004; Vincent et al. 2004). Vincent et al. (2004) described psychiatric symptoms in VGKC autoimmunity not associated with tumors, highlighting the concept of non-paraneoplastic autoimmunity. The psychiatric spectrum became amplified 10 years later as personality changes, depressive syndrome and anxiety in 67 patients with VGKC serum antibodies. Depression and anxiety were observed in $62 \%$ of these patients (Somers et al. 2011). Another investigation reported mood dysfunction and anxiety in $17 \%$ of 316 patients with VGKC antibodies (Klein et al. 2013). Cognitive dysfunction was more deeply investigated by Butler et al. (2014), who found that some patients with VGKC encephalitis exhibited relevant memory impairment, decelerated processing, and executive dysfunction. Furthermore, some patients revealed persistent anterograde amnesia even when other symptoms were immunotherapy responsive. In a smaller cohort of six patients with VGKC antibody-positive probable autoimmune encephalitis, other distinct psychiatric features such as suicidal thoughts, mania or psychosis was observed (Kruse et al. 2015). In their recent review, Prüss and Lennox (2016) analyzed 13 patients with neuropsychiatric symptoms who revealed additional psychiatric symptoms such as mood and cognitive dysfunction, as well as sleep disturbances.

\section{NMDAR antibody-positive encephalitis}

The most prevalent (and often diagnosed as "psychiatric") encephalitis is associated with NMDAR antibodies. In NMDAR encephalitis, the psychiatric symptoms even precede the appearance of neurologic symptoms (Dalmau et al. 2019). A typical constellation is an abrupt onset of psychiatric symptoms such as delusions, amnesia or agitation with no prior psychiatric history (Marinova et al. 2019). In Sansing et al. (2007) described a woman who exhibited a variety of psychiatric symptoms such as mainly behavioral transformations such as aggression and agitation as well as anxiety and even homicidal ideation (Fig. 1). A large cohort of 100 patients was described a year later by Dalmau (2008). All of their patients presented with psychiatric symptoms including memory disturbances (they unfortunately failed to characterize the psychiatric symptoms further). Other single case reports 
augmented the psychiatric spectrum potentially associated with NMDAR encephalitis. A woman with NMDAR encephalitis displayed catatonia in 2009 (Khadem 2009), a symptom that has since then often been considered as pathognomonic for NMDAR encephalitis (EspinolaNadurille et al. 2019). In NMDAR encephalitis, patients often present a catatonic syndrome including delirium, psychomotor agitation, and hallucinations; immunotherapy has delivered very promising results (Espinola-Nadurille et al. 2019). The first report of an acute psychosis was published in 2010 (Fawcett et al. 2010) and later confirmed by others (Tidswell et al. 2013). In their large observation group of 571 patients, Kayser et al. (2013) explored the spectrum of isolated psychiatric symptoms found in $4 \%$ of NMDAR-positive encephalitis patients. This spectrum comprised behavioral symptoms such as aggression, disinhibition and suicidality, psychotic syndrome comprising delusions, mood changes including mania and depression, and catatonic symptoms such as echolalia (referring to classification Al-Diwani et al. (2019)) and catatonia. The most frequent symptoms were mood dysfunction in $70 \%$, delusions in $74 \%$, aggression in $57 \%$ and auditory or visual hallucinations in 43\% (Kayser et al. 2013). $83 \%$ of these patients recovered following immunotherapy or tumor removal, as had been diagnosed in $43 \%$ (Kayser et al. 2013). Schizophreniform psychosis is a frequent phenomenon and has been supported by a recent study of a 60-patient cohort of patients suffering first-episode psychosis and additional neurological features such as seizures or autonomic symptoms [27\% of these patients had been diagnosed with NMDAR encephalitis] (Tang et al. 2019). The complex psychiatric presentation of NMDAR encephalitis was enriched in subsequent years to incorporate bipolar mood dysfunction and mania (Choe et al. 2013; Fousse et al. 2013), anxiety (Maat et al. 2013) and behavioral abnormalities including agitation (Maat et al. 2013). Psychotic and depressive syndrome often coexist, as reported by a large-scale study of Al-Diwani et al. (2019) including 505 patients reported with psychiatric symptomatology in NMDAR encephalitis.

\section{AMPAR-positive encephalitis}

The autoantibody against the AMPAR receptor was reported in ten patients with limbic encephalitis in 2009 (Fig. 1). Antibodies against AMPAR might impair learning and memory, as a recent in vitro and in vivo study in mice demonstrated (Haselman et al. 2008). Their patients revealed a phenotype consisting of behavioral abnormalities including agitation and lethargy, short-term memory dysfunction, confabulation, disorientation, hallucinations and insomnia (Lai et al. 2009). Applying these antibodies to neuronal cultures reduced the size of AMPAR aggregations at the synapse (Lai et al. 2009), suggesting synaptic dysfunction as a probable pathophysiological basis of various psychiatric symptoms such as memory dysfunction induced by AMPAR antibodies (O'Reilly et al. 2019). Another case report indicated that rapid cycling bipolar symptoms could also suggest AMPAR encephalitis (Quaranta et al. 2015).

\section{LGI1-positive encephalitis}

Another antibody is directed against the LGI1 antigen, which is part of the VGKC complex interacting with presynaptic ADAM metallopeptidase domain 23 (ADAM23) and postsynaptic ADAM metallopeptidase domain 22 (ADAM22). LGI1 antibodies might induce neuronal apoptosis, as recently demonstrated in hippocampal neurons (Aysit-Altuncu et al. 2018), potentially leading to irreversible neuronal dysfunction and thus diverse symptoms such as episodic memory dysfunction. Memory disturbances are a frequent symptom, reported in 57 patients with serum and CSF VGKC antibodies (Lai et al. 2010) (Fig. 1). Memory impairment in LGI1 patients was related to stronger functional connectivity with the insula brain region, salience network, and default mode network, indicating network-based impairments due to LGI1 encephalitis (Heine et al. 2018). Over the last 5 years, more psychiatric symptoms such as depressive syndrome (Murata et al. 2015), mania (Tu et al. 2018) and psychosis (Wang et al. 2018) have been described as manifesting as the main clinical presentations. These psychiatric manifestations may be attributable to impaired connectivity in those brain regions involved in motion and cognition (Qiao et al. 2020).

\section{CASPR2-positive encephalitis}

In the same year that CASPR2 antibodies were identified as also being part of the VGKC complex in patients with LGI1 encephalitis, patients with CASPR2-positive encephalitis were clinically characterized by confusion, amnesia, and hallucinations (Vincent and Irani 2010) (Fig. 1). In patients with CASPR2 CSF-positive encephalitis, memory dysfunction was a primordial feature of the phenotypology (Joubert et al. 2016). CASPR2 encephalitis' psychotic phenomenology was recently reported in conjunction with postpartum psychosis (Warren et al. 2019).

\section{GABAAR- and GABABR-positive encephalitis}

In addition to CASPR2 LGI1 encephalitis, further autoantibodies termed GABABR antibodies were reported in 2010 to be associated with memory dysfunction, confusion, behavioral abnormalities, and psychosis (Lancaster et al. 2010) (Fig. 1). Although GABABR-positive encephalitis' 
pathophysiology is still not well understood, a study revealed that $\mathrm{CD} 8+\mathrm{T}$ cells are major players in GABABR-positive encephalitis (Golombeck et al. 2016). GABAAR-antibody encephalitis was discovered 4 years later in patients presenting with cognitive impairment (Petit Pedrol et al. 2014) (Fig. 1). The phenotype was characterized by episodic memory dysfunction, confusion, agitation, and catatonic features such as echolalia and mutism (Si et al. 2019; Samra et al. 2020). (Al Diwani's classification of psychiatric features (Al Diwani et al. 2019)).

\section{GAD65-positive encephalitis}

2010 temporal lobe epilepsy due to limbic encephalitis associated with serum and CSF GAD65 antibodies was first described by Malter in a small cohort of patients (Malter et al. 2010) (Fig. 1). Stiff person autoimmune serum autoantibodies suffice, but for others, like autoimmune encephalitis, intrathecal GAD65 is required to confirm autoimmunity (Graus et al. 2020). GAD65-positive encephalitis was diagnosed in a woman with depressive syndrome, cognitive impairment, and autoimmune polyendocrinopathy-candidiasis-ectodermal dystrophy (APECED) syndrome diagnosed after detecting CSF antibodies (Kopczak et al. 2017) and confirming their relevance to autoimmunity. Mood dysfunction and cognitive impairment are frequent symptoms in GAD65-positive encephalitis (Hansen et al. 2016; Hansen et al. 2018). Furthermore verbal and figural memory deficits are often diagnosed in conjunction with GAD65 encephalitis over long time intervals (Hansen et al. 2018). The morphological basis for severe disturbances in emotional regulation is probably the amygdala's altered volume and signal intensity that GAD65-positive patients with limbic encephalitis have revealed (Wagner et al. 2015).

\section{Autoimmune encephalitis subtypes associated with autoantibodies against membrane surface antigens}

In 2005, the serum and CSF autoantibody against a protein termed EFA6A (that interacts with potassium channels) was reported to be associated with a paraneoplastic encephalitis associated with a depressive syndrome, incoherent thoughts, insomnia, panic, personality changes and psychotic symptoms such as delusional thinking and auditory hallucinations (Vitaliani et al. 2005) (Fig. 1). An encephalitis subtype associated with serum CRMP3/4 antibodies was first reported in 2007 (Kudsen et al. 2007) (Fig. 1). Its symptomatology ranges from cognitive decline to agitation and hallucinations. This antigen protein is involved in nerve neural growth. CRMP3/4 antibodies were stained in synaptic pyramidal cells and granule cells in the hippocampus. Due to the key role the hippocampus plays in memory and cognition, these CRMP3/4 antibodies-identified on hippocampal pyramidal and granule cells-might explain the aforementioned cognitive dysfunction. Four years later, two patients with limbic encephalitis presenting with serum mGluR5receptor antibodies were determined suffering from fear, agitation, auditory and visual hallucinations, and suicidal thoughts (Lancaster et al. 2011) (Fig. 1). Later, the spectrum of psychiatric symptoms was expanded to include inattention and anterograde memory impairments (Guevara et al. 2018). This variable psychiatric spectrum including memory dysfunction and anxiety might result from mGLUR5 involvement in synaptic transmission and neuromodulatory control over neuronal networks (Ibrahim et al. 2020), and in its dysfunction when blocked by mGluR5 antibodies. The novel antibody against the DPPX antigen as a subunit of Kv4.2 potassium channels was proven via immunoprecipitation and mass spectrometry in four patients (Boronat et al. 2013) associated with agitation and confusion as psychiatric symptomatology (Fig. 1). Several novel antibodies associated with encephalitis have been reported in the last 5 years, such as synapsin and neurexin 3 alpha antibodies. Both synapsin as a vesicle-colocated protein at the synapse (Piepgras et al. 2015) and neurexin3alpha as a cell-adhesion protein (Gresa-Arribas et al. 2016) are important for regulating synaptic function. Thus, it is not surprising that confusion (Piepgras et al. 2015; Gresa-Arribas et al. 2016) and disorientation were observed as prominent symptoms in patients diagnosed with synapsin and neurexin 3 alpha encephalitis (Fig. 1). We have been aware of glycine-receptor antibodies for years, i.e., in stiff person spectrum disorders such as progressive encephalomyelitis with stiffness and rigidity (PERM). However, these antibodies were observed just 2 years ago in relation to the clinical appearance of cognitive dysfunction (Swayne et al. 2018) (Fig. 1). Serum and CSF IgLON5 antibodies provide another example, as they can induce an encephalitis often associated with cognitive dysfunction (Simabukuro et al. 2015) (Fig. 1) including figural memory deficits (Hansen et al. 2020a) in addition to neurological deficits. Serum and CSF KLP11 antibodies were recently described in young male patients presenting with ocular symptoms and vertigo together with a seminoma (Mandel-Brehm et al. 2019). These serum and CSF KLP11 antibodies were additionally reported to be associated with psychosis in a further investigation (Maudes et al. 2020), although the mechanistic basis of these antibodies generating psychosis is unclear (Fig. 1). 


\section{Discussion}

\section{Synopsis: psychiatric symptoms in subtypes of autoimmune encephalitis}

Our review shows that, as identified through various CSF autoantibodies, specific types of autoimmunity are associated with a psychiatric spectrum comprising disorientation, cognitive and memory dysfunction, behavioral abnormalities, psychosis, mood dysfunction, anxiety, obsessive-compulsive behavior, catatonia and sleeping dysfunction. Suicidality in autoimmune encephalitis patients has only been reported in conjunction with serum VGKC and mGluR5 autoantibodies. This evidence suggests that there are no specific autoantibodies in autoimmune encephalitis patients associated with specific symptoms apart from CSF NMDA autoantibodies in catatonia, or serum $\mathrm{Ma} / \mathrm{Ta}$ autoantibodies in obsessive-compulsive behavior. The psychiatric syndrome and symptoms in autoimmune encephalitis patients are associated with various autoantibodies. These data show that it would be worthwhile to test for a panel of autoantibodies and not just specific autoantibodies in patients presenting with psychiatric symptoms. Furthermore, it is mainly those autoantibodies against membrane surface antigens in encephalitis patients that are associated with psychiatric features, as these autoantibodies interfere with neurotransmission, and psychiatric symptoms are often caused by impaired neurotransmission.

\section{Prospective challenges}

Our main challenge is to describe the psychiatric phenotype of autoimmune encephalitis patients associated with autoantibodies. There have been no large-scale prospective or retrospective studies investigating various autoantibodies. Discovering a specific psychiatric phenotype in patients with specific autoantibody-positive autoimmune encephalitis would be of major interest to enable specific and effective treatment for these patients. Further prospective challenges concern views of underlying immune pathophysiology of autoimmune encephalitis associated with psychiatric symptoms. More cause-effect studies are needed to better understand the role of autoantibodies. Prior studies involving the transfer of human autoantibodies to rodents ranging from $\alpha$-amino-3-hydroxy-5-methyl-4-isoxazolepropionic acid receptor (AMPAR), glutamic acid decarboxylase 65 (GAD65), glycine- or leucine-rich glioma-inactivated 1 (LGI1) or NMDAR autoantibodies have demonstrated that neural transmission on the cellular level with consecutive, altered signal cascades could induce psychiatry symptoms and cognitive anomalies on the behavioral level (Haselmann et al. 2018; Planaguma et al. 2015; Jurek et al. 2019; Geis et al. 2012; Petit Pedrol et al. 2018). These animal model studies confirm that autoantibodies play a pathogenic role in inducing psychiatric and neurocognitive symptoms in autoimmune encephalitis patients. However, further studies should be conducted to elucidate the exact role of autoantibody subgroups and their correlation to psychopathology assessed via different psychometric approaches. In this sense, novel research tools for classification of psychopathology as the hierarchical taxonomy of psychopathology comprising spectra and subfactors (Ruggero et al. 2019; Kotov et al. 2020) apart from the standard assessment according to Diagnostic and Statistical Manual of Mental Disorders Fifth Edition (DSM V) are promising. Apart from the relationship between psychopathology and autoantibodies, the relationship between immune cell subsets as potential biomarkers of autoimmune encephalitis (Hansen et al. 2020b, c) is interesting, as a recent study demonstrated a potential role of cerebrospinal fluid B- and T-cell activity and cognitive dysfunction in suspected limbic encephalitis (Helmstaedter et al. 2020). Thus, we are interested in assessing CSF sets and subsets of immune cell populations via fluorescenceactivated cell sorting analysis in patients with autoimmune encephalitis and predominant psychiatric symptoms to identify patterns of immune cells, thereby providing new insight into the pathophysiologic mechanisms generating psychiatric symptoms in autoimmune encephalitis. Seeking such immune-cell subsets is particularly worthwhile, as a recent study revealed that in NMDAR encephalitis, the clinical syndrome psychosis' generation is not associated with NMDAR autoantibodies (Engen et al. 2020), suggesting that the role that NMDAR autoantibodies play in immunopathology is being overrated.

\section{Conclusions}

As psychiatric symptoms and syndromes have been less intensively investigated than neurological deficits and symptoms in autoimmune encephalitis patients, these symptoms may be underdiagnosed in patients with autoimmune encephalitis: There is thus a great need for more detailed descriptions of psychiatric syndromes and symptoms in patients with autoimmune encephalitis to enable the psychiatric features of this disease to be better characterized, thereby ensuring these patients receive more effective therapy following a psychiatric onset or predominantly psychiatric manifestation of autoimmune encephalitis.

Author contributions $\mathrm{NH}$ performed literature research and wrote the manuscript. CT revised the manuscript for intellectual content. 
Funding Open Access funding enabled and organized by Projekt DEAL.

\section{Compliance with ethical standards}

Conflict of interest The authors declare no conflicts of interest.

Open Access This article is licensed under a Creative Commons Attribution 4.0 International License, which permits use, sharing, adaptation, distribution and reproduction in any medium or format, as long as you give appropriate credit to the original author(s) and the source, provide a link to the Creative Commons licence, and indicate if changes were made. The images or other third party material in this article are included in the article's Creative Commons licence, unless indicated otherwise in a credit line to the material. If material is not included in the article's Creative Commons licence and your intended use is not permitted by statutory regulation or exceeds the permitted use, you will need to obtain permission directly from the copyright holder. To view a copy of this licence, visit http://creativecommons.org/licenses/by/4.0/.

\section{References}

Al-Diwani A, Handel A, Townsend L, Pollak T, Leite MI, Harrison PJ et al (2019) The psychopathology of NMDAR-antibody encephalitis in adults: a systematic review and phenotypic analysis of individual patient data. Lancet Psychiatry 6:235-246. https://doi. org/10.1016/S2215-0366(19)30001-X

Ayşit-Altuncu N, Ulusoy C, Öztürk G, Tüzün E (2018) Effect of LGI1 Antibody-Positive IgG on Hippocampal neuron survival: a preliminary study. NeuroReport 29:932-938. https://doi. org/10.1097/WNR.0000000000001055

Barbero JD, Palacín A, Serra P, Solé M, Ortega L, Cabezas Á et al (2019) Association between anti-thyroid antibodies and negative symptoms in early psychosis. Early Interv Psych 14:470-475. https://doi.org/10.1111/eip.12873

Barbuti M, Carvalho AF, Köhler CA, Murru A, Verdolini N, Guiso $\mathrm{G}$ et al (2017) Thyroid autoimmunity in bipolar disorder: a systematic review. J Affect Disord 221:97-106. https://doi. org/10.1016/j.jad.2017.06.019

Bien CI, Nehls F, Kollmar R, Weis M, Steinke W, Woermann F et al (2019) Identification of adenylate kinase 5 antibodies during routine diagnostics in a tissue-based assay: three new cases and a review of the literature. J Neuroimmunol 334:576975. https:// doi.org/10.1016/j.jneuroim.2019.576975

Boronat A, Gelfand JM, Gresa-Arribas N, Jeong HY, Walsh M, Roberts K, Martinez-Hernandez E, Rosenfeld MR, Balice-Gordon R, Graus F, Rudy B, Dalmau J (2013) Encephalitis and antibodies to dipeptidyl-peptidase-like protein-6, a subunit of Kv4.2 potassium channels. Ann Neurol 73:120-128. https://doi.org/10.1002/ ana.23756

Brierley JB, Corsellis JAN, Hierons R, Nevin S (1960) Subacute encephalitis of later adult life. Mainly affecting the limbic areas. Brain 83:357-368. https://doi.org/10.1093/brain/83.3.357

Buckley C, Oger J, Clover L, Tüzün E, Carpenter K, Jackson M et al (2001) Potassium channel antibodies in two patients with reversible limbic encephalitis. Ann Neurol 50:73-78. https://doi. org/10.1002/ana.1097

Butler CR, Miller TD, Kaur MS, Baker IW, Boothroyd GD, Illman NA, Rosenthal CR, Vincent A, Buckley CJ (2014) Persistent anterograde amnesia following limbic encephalitis associated with antibodies to the voltage-gated potassium channel complex. J Neurol
Neurosurg Psychiatry 85:387-391. https://doi.org/10.1136/jnnp2013-306724

Camdessanché JP, Lassablière F, Meyronnet D, Férraud K, Absi L, Honnorat J, Antoine JC (2006) Expression of the onconeural CV2/CRMP5 antigen in thymus and thymoma. J Neuroimmunol 174:168-173. https://doi.org/10.1016/j.jneuroim.2006.01.018

Choe CU, Karamatskos E, Schattling B, Leypoldt F, Liuzzi G, Gerloff C, Friese MA, Mulert C (2013) A clinical and neurobiological case of IgM NMDA receptor antibody associated encephalitis mimicking bipolar disorder. Psychiatry Res 208:194-196. https ://doi.org/10.1016/j.psychres.2012.09.035

Corsellis JA, Goldberg GJ, Norton AR (1968) "Limbic Encephalitis" and its association with carcinoma. Brain 91:481-496. https:// doi.org/10.1093/brain/91.3.481

Dalmau J, Graus F, Villarejo A, Posner JB, Blumenthal D, Thiessen B et al (2004) Clinical analysis of anti-Ma2-associated encephalitis. Brain 127:1831-1844. https://doi.org/10.1093/brain/awh203

Dalmau J, Gleichman AJ, Hughes EG, Rossi JE, Peng X, Lai M et al (2008) Anti-NMDA-receptor encephalitis: case series and analysis of the effects of antibodies. Lancet Neurol 7:1091-1098. https ://doi.org/10.1016/S1474-4422(08)70224-2

Dalmau J, Armangué T, Planagumà J, Radosevic M, Mannara F, Leypoldt F, Geis C, Lancaster E, Titulaer MJ, Rosenfeld MR, Graus F (2019) An update on anti-NMDA receptor encephalitis for neurologists and psychiatrists: mechanisms and models. Lancet Neurol 18:1045-1057. https://doi.org/10.1016/S1474 -4422(19)30244-3

Do LD, Chanson E, Desestret V, Joubert B, Ducray F, Brugiere S et al (2017) Characteristics in limbic encephalitis with anti-adenylate kinase 5 autoantibodies. Neurology 88:514-524. https://doi. org/10.1212/WNL.0000000000003586

Dogan Onugoren M, Deuretzbacher D, Haensch CA, Hagedorn HJ, Halve $S$ et al (2015) Limbic encephalitis due to GABAB and AMPA receptor antibodies: a case series. J Neurol Neurosurg Psychiatry 86:965-972. https://doi.org/10.1136/jnnp-2014-30881 4

Endres DS, Perlov E, Stich O, Meyer PT, Lützen N, van Elst LT (2015) Case report: low-titre anti-yo reactivity in a female patient with psychotic syndrome and frontoparieto-cerebellar atrophy. BMC Psychiatry 12:15-112. https://doi.org/10.1186/s1288 8-015-0486-x

Engen K, Wortinger LA, Nordbø Jørgensen K, Lundberg M, Bohman $\mathrm{H}$, Smelror RE et al (2020) Autoantibodies to the $N$-Methyl$\mathrm{D}$-aspartate receptor in adolescents with early onset psychosis and healthy controls. Front Psychiatry 11:666. https://doi. org/10.3389/fpsyt.2020.00666

Espinola-Nadurille M, Flores-Rivera J, Rivas-Alonso V, Vargas-Cañas S, Fricchione GL, Bayliss L, Martinez-Juarez IE, HernandezVanegas LE, Martinez-Hernandez R, Bautista-Gomez P, SolisVivanco R, Perez-Esparza R, Bustamante-Gomez PA, RestrepoMartinez M, Ramirez-Bermudez J (2019) Catatonia in patients with anti-NMDA receptor encephalitis. Psychiatry Clin Neurosci 73:574-580. https://doi.org/10.1111/pcn.12867

Fawcett RG (2010) Acute psychosis associated with anti-nmda-receptor antibodies and bilateral ovarian teratomas: a case report. J Clin Psychiatry 71:504. https://doi.org/10.4088/JCP.09105609yel

Finke C, Kopp UA, Prüss H, Dalmau J, Wandinger KP, Ploner CJ (2012) Cognitive deficits following anti-NMDA receptor encephalitis. J Neurol Neurosurg Psychiatry. 83:195-198. https://doi. org/10.1136/jnnp-2011-300411

Fousse M, Becker C, Faßbender K, Reith W, Körner H, Alexandrou M, Spiegel J (2013) First occurrence of an organic manic schizophreniform syndrome followed by catatonia induced by anti-NMDA-receptor encephalitis. Fortschr Neurol Psychiatr 81:206-209. https://doi.org/10.1055/s-0033-1335044 
Geis C, Grünewald B, Weishaupt A, Wultsch T, Toyka KV, Reif A et al (2012) Human IgG directed against amphiphysin induces anxiety behaviour in a rat model after intrathecal passive transfer. J Neural Transm 119:981-985

Golombeck KS, Bönte K, Mönig C, van Loo KM, Hartwig M, Schwindt W, Widman G, Lindenau M, Becker AJ, Glatzel M, Elger CE, Wiendl H, Meuth SG, Lohmann H, Gross CC, Melzer $\mathrm{N}$ (2016) Evidence of a pathogenic role for CD8+ T-cells in anti-GABAB receptor limbic encephalitis. Neurol Neuroimmunol Neuroinflamm 3:232

Graus F, Keime-Guibert F, Reñe R, Benyahia B, Ribalta T, Ascaso C, Escaramis G, Delattre JY (2001) Anti-Hu-associated paraneoplastic encephalomyelitis: analysis of 200 patients. Brain $124(\mathrm{Pt}$ 6):1138-1148. https://doi.org/10.1093/brain/124.6.1138 PMID: 11353730

Graus F, Titulaer MJ, Balu R, Benseler S, Bien CG, Cellucci T et al (2016) A clinical approach to diagnosis of autoimmune encephalitis. Lancet Neurol 15:391-404

Graus F, Saiz A, Dalmau J (2020) GAD antibodies in neurological disorders - insights and challenges. Nat Rev Neurol. https://doi. org/10.1038/s41582-020-0359-X

Gresa-Arribas N, Planaguma J, Petit-Pedrol M, Kawachi I, Katada S et al (2016) Human neurexin-3alpha antibodies associate with encephalitis and alter synapse development. Neurology 86:22352242. https://doi.org/10.1212/WNL.0000000000002775

Guevara C, Farias G, Silva-Rosas C, Alarcon P, Abudinen G, Espinoza J, Caro A, Angus-Leppan H, de Grazia J (2018) Encephalitis associated to metabotropic glutamate receptor 5 (mGluR5) antibodies in cerebrospinal fluid. Front Immunol 5(9):2568. https:// doi.org/10.3389/fimmu.2018.02568

Hansen N, Widman G, Witt JA, Wagner J, Becker AJ, Elger CE et al (2016) Seizure control and cognitive improvement via immunotherapy in late onset epilepsy patients with paraneoplastic versus GAD65 autoantibody-associated limbic encephalitis. Epilepsy Behav 65:18-24. https://doi.org/10.1016/j.yebeh .2016

Hansen N, Ernst L, Rüber T, Widman G, Becker AJ, Elger CE, Helmstaedter C (2018) Pre- and long-term postoperative courses of hippocampus-associated memory impairment in epilepsy patients with antibody-associated limbic encephalitis and selective amygdalohippocampectomy. Epilepsy Behav 79:93-99. https ://doi.org/10.1016/j.yebeh.2017.10.033

Hansen N, Hirschel S, Stöcker W, Manig A, Falk HS, Ernst MS, Vukovich R, Zerr I, Wiltfang J, Bartels C (2020a) Figural memory impairment in conjunction with neuropsychiatric symptoms in IgLON5 antibody-associated autoimmune encephalitis. Front Psych 11:576

Hansen N, Schwing K, Önder D, Widman G, Leelaarporn P, Prusseit I et al (2020b) Low CSF CD4/CD8+ T-cell proportions are associated with blood- CSF barrier dysfunction in limbic encephalitis. Epilepsy Behav 102:106682. https://doi.org/10.1016/j.yebeh .2019 .106682

Hansen N, Önder D, Schwing K, Widman G, Leelaarporn P, Prusseit I et al (2020c) CD19+ B-cells in autoantibody-negative limbic encephalitis. Epilepsy Behav 106:107016. https://doi. org/10.1016/j.yebeh.2020.107016

Hara M, Ariño H, Petit-Pedrol M, Sabater L, Titulaer MJ, MartinezHernandez E, Schreurs MW, Rosenfeld MR, Graus F, Dalmau J (2017) DPPX antibody-associated encephalitis: main syndrome and antibody effects. Neurology 88:1340-1348. https://doi. org/10.1212/WNL.0000000000003796

Harloff A, Hummel S, Kleinschmidt M, Rauer S (2005) Anti-Ri antibodies and limbic encephalitis in a patient with carcinoid tumour of the Lung. J Neurol 252:1404-1405

Haselmann H, Mannara F, Werner C, Planagumà J, Miguez-Cabello F, Schmidl L, Grünewald B, Petit-Pedrol M, Kirmse K, Classen J,
Demir F, Klöcker N, Soto D, Doose S, Dalmau J, Hallermann S, Geis C (2018) Human autoantibodies against the AMPA receptor subunit GluA2 induce receptor reorganization and memory dysfunction. Neuron 100(1):91-105.e9. https://doi.org/10.1016/j. neuron.2018.07.048

Haselmann H, Mannara F, Werner C, Planagumà J, Miguez-Cabello F, Schmidl L et al (2018) Human autoantibodies against the AMPA receptor subunit GluA2 induce receptor reorganization and memory dysfunction. Neuron 100:91-105

Heine J, Prüss H, Kopp UA, Wegner F, Then Bergh F, Münte T, Wandinger KP, Paul F, Bartsch T, Finke C (2018) Beyond the limbic system: disruption and functional compensation of large-scale brain networks in patients with anti-LGI1 encephalitis. J Neurol Neurosurg Psychiatry 89:1191-1199. https://doi. org/10.1136/jnnp-2017-317780

Helmstaedter C, Hansen N, Leelaarporn P, Schwing K, Oender D, Widman G et al (2020) Specific B- and T-cell populations are associated with cognition in patients with epilepsy and antibody positive and negative suspected limbic encephalitis. J Neurol. https://doi.org/10.1007/s00415-020-10158-1

Herken J, Prüss H (2017) Red flags: clinical signs for identifying autoimmune encephalitis in psychiatric patients. Front Psychiatry 8:25. https://doi.org/10.3389/fpsyt.2017.00025

Hirayama K, Taguchi Y, Sato M, Tsukamoto T (2003) Limbic encephalitis presenting with topographical disorientation and amnesia. J Neurol Neurosurg Psychiatry 74:110-112. https://doi. org/10.1136/jnnp.74.1.110

Hoffmann LA, Jarius S, Pellkofer HL, Schueller M, Krumbholz M, Koenig F et al (2008) Anti-Ma and anti-Ta associated paraneoplastic neurological syndromes: 22 newly diagnosed patients and review of previous cases. J Neurol Neurosurg Psychiatry 79:767-773. https://doi.org/10.1136/jnnp.2007.118588

Höftberger R, Titulaer MJ, Sabater L, Dome B, Rózsás A, Hegedus B et al (2013) Encephalitis and GABAB receptor antibodies: novel findings in a new case series of 20 patients. Neurology 22(81):1500-1506. https://doi.org/10.1212/WNL.0b013e3182 a9585f

Höftberger R, van Sonderen A, Leypoldt F, Houghton D, Geschwind M, Gelfand J et al (2015) Encephalitis and AMPA receptor antibodies: novel findings in a case series of 22 patients. Neurology 84:2403-2412. https://doi.org/10.1212/WNL.0000000000 001682

Honnorat J, Antoine JC, Derrington E, Aguera M, Belin MF (1996) Antibodies to a subpopulation of glial cells and a $66 \mathrm{kDa}$ developmental protein in patients with paraneoplastic neurological syndromes. J Neurol Neurosurg Psychiatry 61:270-278. https:// doi.org/10.1136/jnnp.61.3.270

Honorat JA, Komorowski L, Josephs KA, Fechner K, St Louis EK, Hinson SR et al (2017) IgLON5 antibody: neurological accompaniments and outcomes in 20 patients. Neurol Neuroimmunol Neuroinflamm. https://doi.org/10.1212/NXI.0000000000000385

Ibrahim KS, Abd-Elrahman KS, Mestikawy SE, Ferguson SS (2020) Targeting VGLUT machinery: implications on mGluR5 signaling and behavior. Mol Pharmacol. https://doi.org/10.1124/molph arm.120.000089

Joubert B, Saint-Martin M, Noraz N, Picard G, Rogemond V, Ducray F, Desestret V, Psimaras D, Delattre JY, Antoine JC, Honnorat J (2016) Characterization of a subtype of autoimmune encephalitis with anti-contactin-associated protein-like 2 antibodies in the cerebrospinal fluid, prominent limbic symptoms, and seizures. JAMA Neurol 73:1115-1124. https://doi.org/10.1001/jamaneurol 2016.1585

Jurek B et al (2019) Human gestational N-methyl-d-aspartate receptor autoantibodies impair neonatal murine brain function. Ann Neurol 86:656-670 
Kayser MS, Titulaer MJ, Gresa-Arribas N, Dalmau J (2013) Frequency and characteristics of isolated psychiatric episodes in anti-N-methyl-D-aspartate receptor encephalitis. JAMA Neurol 70:1133-1139. https://doi.org/10.1001/jamaneurol.2013.3216

Khadem GM, Heble S, Kumar R, White C (2009) Anti-N-methylD-aspartate receptor antibody limbic encephalitis. Intern Med J 39:54-56. https://doi.org/10.1111/j.1445-5994.2008.01808.x

Klein CJ, Lennon VA, Aston PA, McKeon A, O'Toole O, Quek A, Pittock SJ (2013) Insights from LGI1 and CASPR2 potassium channel complex autoantibody subtyping. JAMA Neurol 70:229-234. https://doi.org/10.1001/jamaneurol.2013.592

Knudsen A, Bredholt G, Storstein A, Oltedal L, Davanger S, Krossnes B, Honnorat J, Vedeler CA (2007) Antibodies to CRMP3-4 associated with limbic encephalitis and thymoma. Clin Exp Immunol 149:16-22. https://doi.org/10.1111/j.1365-2249.2007.03379.x

Kopczak A, Schumacher AM, Nischwitz S, Kümpfel T, Stalla GK (2017) Auer MK (2017) GAD antibody-associated limbic encephalitis in a young woman with APECED. Endocrinol Diabetes Metab Case Rep 2017:17-0010. https://doi.org/10.1530/ EDM-17-0010.eCollection

Kotov R, Jonas KG, Carpenter WT, Dretsch MN, Eaton NR, Forbes MK, Workgroup HU et al (2020) Validity and utility of hierarchical taxonomy of psychopathology (HiTOP): I Psychosis superspectrum. World Psychiatry 19:151-172. https://doi.org/10.1002/ wps. 20730

Kruse JL, Lapid MI, Lennon VA, Klein CJ, Toole OO, Pittock SJ, Strand EA, Frye MA, McKeon A (2015) Psychiatric autoimmunity: N-Methyl-D-Aspartate Receptor IgG and beyond. Psychosomatics 56:227-241. https://doi.org/10.1016/j.psym.2015.01.003

Lai M, Hughes EG, Peng X, Zhou L, Gleichman AJ, Shu H et al (2009) AMPA receptor antibodies in limbic encephalitis alter synaptic receptor location. Ann Neurol 65:424-434. https://doi. org/10.1002/ana.21589

Lai M, Huijbers MG, Lancaster E, Graus F, Bataller L, Balice-Gordon $\mathrm{R}$ et al (2010) Investigation of LGI1 as the antigen in limbic encephalitis previously attributed to potassium channels: a case series. Lancet Neurol 9:776-785. https://doi.org/10.1016/S1474 -4422(10)70137-X

Lancaster E, Lai M, Peng X, Hughes E, Constantinescu R, Raizer J, Friedman D, Skeen MB, Grisold W, Kimura A, Ohta K, Iizuka T, Guzman M, Graus F, Moss SJ, Balice-Gordon R, Dalmau J (2010) Antibodies to the GABA(B) receptor in limbic encephalitis with seizures: case series and characterisation of the antigen. Lancet Neurol 9:67-76. https://doi.org/10.1016/S1474 $-4422(09) 70324-2$

Lancaster E, Martinez-Hernandez E, Dalmau J (2011) Encephalitis and antibodies to synaptic and neuronal cell surface proteins. Neurology 77:179-189. https://doi.org/10.1212/WNL.0b013 e318224afde

Loane C, Argyropoulos GPD, Roca-Fernández A, Lage C, Sheerin F, Ahmed S et al (2019) Hippocampal network abnormalities explain amnesia after VGKCC-Ab related autoimmune limbic encephalitis. J Neurol Neurosurg Psychiatry 90:965-974. https ://doi.org/10.1136/jnnp-2018-320168

Maat P, de Graaff E, van Beveren NM, Hulsenboom E, Verdijk RM, Koorengevel K et al (2013) Psychiatric phenomena as initial manifestation of encephalitis by anti-NMDAR antibodies. Acta Neuropsychiatr 25:128-136. https://doi.org/10.1111/acn.12013

Malter MP, Helmstaedter C, Urbach H, Vincent A, Bien CG (2010) Antibodies to glutamic acid decarboxylase define a form of limbic encephalitis. Ann Neurol 67:470-478. https://doi. org/10.1002/ana.21917

Mandel-Brehm C, Dubey D, Kryzer TJ, O'Donovan BD, Tran B, Vazquez SE, Sample HA, Zorn KC, Khan LM, Bledsoe IO, McKeon A, Pleasure SJ, Lennon VA, DeRisi JL, Wilson MR,
Pittock SJ (2019) Kelch-like protein 11 antibodies in seminomaassociated paraneoplastic encephalitis. N Engl J Med 4(381):4754. https://doi.org/10.1056/NEJMoa1816721

Marinova Z, Bausch-Becker N, Savaskan E (2019) Anti- N-methyl$\mathrm{d}$-aspartate receptor encephalitis in an older patient presenting with a rapid onset of delusions and amnesia. BMJ Case Rep 12:e228512

Maudes E, Landa J, Muñoz-Lopetegi A, Armangue T, Alba M, Saiz A, Graus F, Dalmau J, Sabater L (2020) Clinical significance of Kelch-like protein 11 antibodies. Neurol Neuroimmunol Neuroinflamm. 17:666. https://doi.org/10.1212/NXI.0000000000 000666

Muehlschlaegel S, Okun MS, Foot KD, Coco D, Yachnis AT, Fernandez HH (2005) Paraneoplastic chorea with leukoencephalopathy presenting with obsessive-compulsive behavioral disorder. Mov Dis 20:1523-1527

Murata Y, Watanabe O, Taniguchi G, Sone D, Fujioka M, Okazaki $M$ et al (2015) A case of autoimmune epilepsy associated with anti-leucine-rich glioma inactivated subunit 1 antibodies manifesting electrical shock-like sensations and transparent sadness. Epilepsy Behav Case Rep 26(4):91-93. https://doi.org/10.1016/j. ebcr.2015.08.004

Ng AS, Kramer J, Centurion A, Dalmau J, Huang E, Cotter JA, Geschwind MD (2015) Clinico-pathological correlation in adenylate kinase 5 autoimmune limbic encephalitis. J Neuroimmunol 287:31-35. https://doi.org/10.1016/j.jneuroim.2015.08.009

Nicollini E et al (2015) Detection of anti-streptococcal, antienolase, and anti-neural antibodies in subjects with early-onset psychiatric disorders. Actas Esp Psiquiatr 43:35-41

Nikolopoulos D, Kostopoulou M, Pieta A, Karageorgas T, Tseronis D, Chavatza K et al (2020) Evolving phenotype of systemic lupus erythematosus in Caucasians: low incidence of lupus nephritis, high burden of neuropsychiatric disease and increased rates of late-onset lupus in the 'Attikon' cohort. Lupus. 29:514-520. https ://doi.org/10.1177/0961203320908932

Oppenheim H (1888) Über Hirnsymptome bei Carcinomatose ohne nachweisbare Veränderungen im Gehirn. Charité Annalen 13:335-344

O'Reilly KC, Perica MI, Fenton AA (2019) Synaptic plasticity/dysplasticity, process memory and item memory in rodent models of mental dysfunction. Schizophr Res 207:22-36. https://doi. org/10.1016/j.schres.2018.08.025

Perrone-Bizzozero N, Bird CW (2013) Role of HuD in nervous system function and pathology. Front Biosci (Schol Ed) 5:554-563. https ://doi.org/10.2741/s389

Petit-Pedrol M, Armangue T, Peng X, Bataller L, Cellucci T, Davis $R$ et al (2014) Encephalitis with refractory seizures, status epilepticus, and antibodies to the GABAA receptor: a case series, characterisation of the antigen, and analysis of the effects of antibodies. Lancet Neurol 13:276-286. https://doi.org/10.1016/ S1474-4422(13)70299-0

Petit-Pedrol M, Sell J, Planagumà J, Mannara F, Radosevic M, Haselmann $\mathrm{H}$ et al (2018) LGI1 antibodies alter Kv1.1. and AMPA receptors changing synaptic excitability, plasticity and memory. Brain 141:3144-3159

Piepgras J, Höltje M, Otto C, Harms H, Satapathy A, Cesca F, Benfenati F, Gitler D, Pich A, Zander JF, Ahnert-Hilger G, Ruprecht $\mathrm{K}$ (2015) Intrathecal immunoglobulin A and $\mathrm{G}$ antibodies to synapsin in a patient with limbic encephalitis. Neurol Neuroimmunol Neuroinflamm 2(6):e169. https://doi.org/10.1212/NXI.00000 00000000169

Piquet AL, Khan M, Warner JEA, Wicklund MP, Bennett JL, Leehey MA, Seeberger L, Schreiner TL, Paz Soldan MM, Clardy SL (2019) Novel clinical features of glycine receptor antibody syndrome: a series of 17 cases. Neurol Neuroimmunol 
Neuroinflamm 6:e592. https://doi.org/10.1212/NXI.0000000000 000592

Pitsch J, Kamalizade D, Braun A, Kuehn JC, Gulakova PE, Rüber T et al (2020) Drebrin autoantibodies in patients with seizures and suspected encephalitis. Ann Neurol 87:869-884. https://doi. org/10.1002/ana.25720

Planaguma J, Leypoldt F, Mannara F, Gutiérrez-Cuesta J, MartínGarcía E, Aguilar E et al (2015) Human N-methyl D aspartate receptor antibodies alter memory and behaviour in mice. Brain 138:94-109

Prüss H, Lennox BR (2016) Emerging psychiatric syndromes associated with antivoltage-gated potassium channel complex antibodies. J Neurol Neurosurg Psychiatry 87:1242-1247

Qiao J, Zhao X, Wang S, Li A, Wang Z, Cao C et al (2020) Functional and structural brain alterations in encephalitis with LGI1 antibodies. Front Neurosci 3(14):304. https://doi.org/10.3389/fnins .2020 .00304

Quaranta G, Maremmani AG, Perugi G (2015) Anti-AMPA-receptor encephalitis presenting as a rapid-cycling bipolar disorder in a young woman with turner syndrome. Case Rep Psychiatry 2015:273192. https://doi.org/10.1155/2015/273192

Ruggero CJ, Kotov R, Hopwood CJ, First M, Clark LA, Skodol AE et al (2019) Integrating the hierarchical taxonomy of psychopathology (HiTOP) into clinical practice. J Consult Clin Psychol 87:1069-1084. https://doi.org/10.1037/ccp0000452

Sabater L, Gómez-Choco M, Saiz A, Graus F (2005) BR serine/ threonine kinase 2: a new autoantigen in paraneoplastic limbic encephalitis. J Neuroimmunol 170:186-190. https://doi. org/10.1016/j.jneuroim.2005.08.011

Sæther SG, Vaaler A, Evjenth A, Aune T, Höltje M, Ruprecht K, Schou M (2019) Subtle phenotype differences in psychiatric patients with and without serum immunoglobulin $\mathrm{G}$ antibodies to synapsin. Front Psychiatry 10:401. https://doi.org/10.3389/fpsyt .2019 .00401

Samra K, Rogers J, Mahdi-Rogers M, Stanton B (2020) Catatonia with GABA(A) receptor antibodies. Pract Neurol 20:139-143. https ://doi.org/10.1136/practneurol-2019-002388

Sansing LH, Tüzün E, Ko MW, Baccon J, Lynch DR, Dalmau J (2007) A patient with encephalitis associated with NMDA receptor antibodies. Nat Clin Pract Neurol 3:291-296. https://doi. org/10.1038/ncpneuro0493

Scheid DR, Voltz R, Guthke T, Bauer J, Sammler D, von Cramon DY (2003) Neuropsychiatric findings in anti-Ma2-positive paraneoplastic limbic encephalitis. Neurology 61:1159-1161

Schulz P, Prüss H (2015) Hirnsymptome bei carcinomatose-hermann oppenheim and an early description of a paraneoplastic neurological syndrome. J Hist Neurosci 24:371-377. https://doi. org/10.1080/0964704X.2015.1021120

Shimasaki C et al (2020) Evaluation of the Cunningham Panel ${ }^{\mathrm{TM}}$ in pediatric autoimmune neuropsychiatric disorder associated with streptococcal infection (PANDAS) and pediatric acute-onset neuropsychiatric syndrome (PANS): changes in antineuronal antibody titers parallel changes in patient symptoms. J Neuroimmunol 339:577138

Si Z, Wang A, Liu J, Zhang Z, Hu K (2019) Typical clinical and imaging manifestations of encephalitis with anti- $\gamma$-aminobutyric acid $B$ receptor antibodies: clinical experience and a literature review. Neurol Sci 40:769-777. https://doi.org/10.1007/s1007 2-018-3679-5

Simabukuro MM, Sabater L, Adoni T, Cury RG, Haddad MS, Moreira $\mathrm{CH}$, Oliveira L, Boaventura M, Alves RC, Azevedo Soster L, Nitrini R, Gaig C, Santamaria J, Dalmau J, Graus F (2015) Sleep disorder, chorea, and dementia associated with IgLON5 antibodies. Neurol Neuroimmunol Neuroinflamm 2(4):e136. https://doi. org/10.1212/NXI.0000000000000136
Somers KJ, Lennon VA, Rundell JR, Pittock SJ, Drubach DA, Trenerry MR, Lachance DH, Klein CJ, Aston PA, McKeon A (2011) Psychiatric manifestations of voltage-gated potassium-channel complex autoimmunity. J Neuropsychiatry Clin Neurosci 23:425-433. https://doi.org/10.1176/jnp.23.4.jnp425

Spatola M, Petit-Pedrol M, Simabukuro MM, Armangue T, Castro FJ, Barcelo Artigues MI, Julià Benique MR, Benson L, Gorman M, Felipe A, Caparó Oblitas RL, Rosenfeld MR, Graus F, Dalmau J (2017) Investigations in GABA(A) receptor antibody-associated encephalitis. Neurology 88:1012-1020. https://doi.org/10.1212/ WNL.0000000000003713

Spatola M, Sabater L, Planagumà J, Martínez-Hernandez E, Armangué T, Prüss H, lizuka T, Caparó Oblitas RL, Antoine JC, Li R, Heaney N, Tubridy N, Munteis Olivas E, Rosenfeld MR, Graus F, Dalmau J (2018) Encephalitis with mGluR5 antibodies: symptoms and antibody effects. Neurology 90:e1964-e1972

Stich O, Klages E, Bischler P, Jarius S, Rasiah C, Voltz R, Rauer S (2012) SOX1 antibodies in sera from patients with paraneoplastic neurological syndromes. Acta Neurol Scand 125:326-331. https ://doi.org/10.1111/j.1600-0404.2011.01572.x

Swayne A, Tjoa L, Broadley S, Dionisio S, Gillis D, Jacobson L, Woodhall MR, McNabb A, Schweitzer D, Tsang B, Vincent A, Irani SR, Wong R, Waters P, Blum S (2018) Antiglycine receptor antibody related disease: a case series and literature review. Eur J Neurol 25:1290-1298. https://doi.org/10.1111/ene.13721

Tang C, Tan K, Lim G, Tan L, Tay KY, Kandiah N, Abdin E, Verma SK (2019) N-Methyl-D-Aspartate (NMDA) receptor and voltagegated potassium channel (VGKC) antibody-associated encephalitides presenting as first episode acute psychosis. Front Psychiatry 10:913. https://doi.org/10.3389/fpsyt.2019.00913

Thieben MJ, Lennon VA, Boeve BF, Aksamit AJ, Keegan M, Vernino S (2004) Potentially reversible autoimmune limbic encephalitis with neuronal potassium channel antibody. Neurology 62:11771182. https://doi.org/10.1212/01.wnl.0000122648.19196.02

Tidswell J, Kleinig T, Ash D, Thompson P, Galletly C (2013) Early recognition of anti-N-methyl D-aspartate (NMDA) receptor encephalitis presenting as acute psychosis. Australas Psychiatry 21:596-599. https://doi.org/10.1177/1039856213506502

Tsukamoto T, Mochizuki R, Mochizuki H, Noguchi M, Kayama H, Hiwatashi M et al (1993) Paraneoplastic cerebellar degeneration and limbic encephalitis in a patient with adenocarcinoma of the colon. J Neurol Neurosurg Psychiatry 56:713-716. https://doi. org/10.1136/jnnp.56.6.713

Tu TH, Chan YE, Bai YM (2018) Anti-leucine-rich glioma-inactivated 1 encephalitis with manic symptoms as the initial manifestation. Aust NZ J Psychiatry 52:714-715. https://doi.org/10.1177/00048 67417742522

Tüzün E, Rossi JE, Karner SF, Centurion AF, Dalmau J (2007) Adenylate kinase 5 autoimmunity in treatment refractory limbic encephalitis. J Neuroimmunol 186:177-180. https://doi. org/10.1016/j.jneuroim.2007.03.015

van Sonderen A, Ariño H, Petit-Pedrol M, Leypoldt F, Körtvélyessy P, Wandinger KP, Lancaster E, Wirtz PW, Schreurs MW, Sillevis Smitt PA, Graus F, Dalmau J, Titulaer MJ (2016) The clinical spectrum of Caspr2 antibody-associated disease. Neurology 87:521-528. https://doi.org/10.1212/WNL.0000000000002917

Varadakar S, Bien CG, Kruse CA, Jensen FE, Bauer J, Pardo CA et al (2014) Rasmussen's encephalitis: clinical features, pathobiology, and treatment advances. Lancet Neurol 13:195-205. https://doi. org/10.1016/S1474-4422(13)70260-6

Vernino S, Tuite P, Adler CH, Meschia JF, Boeve BF, Boasberg P, Parisi JE, Lennon VA (2002) Paraneoplastic chorea associated with CRMP-5 neuronal antibody and lung carcinoma. Ann Neurol 51:625-630. https://doi.org/10.1002/ana.10178 
Vincent A, Irani SR (2010) Caspr2 antibodies in patients with thymomas. J Thorac Oncol 5(10 Suppl 4):S277-280. https://doi. org/10.1097/JTO.0b013e3181f23f04

Vincent A, Buckley C, Schott JM, Baker I, Dewar BK, Detert N, Clover L, Parkinson A, Bien CG, Omer S, Lang B, Rossor MN, Palace J (2004) Potassium channel antibody-associated encephalopathy: a potentially immunotherapy-responsive form of limbic encephalitis. Brain 127(Pt 3):701-712. https://doi.org/10.1093/ brain/awh077

Vitaliani R, Mason W, Ances B, Zwerdling T, Jiang Z, Dalmau J (2005) Paraneoplastic encephalitis, psychiatric symptoms, and hypoventilation in ovarian teratoma. Ann Neurol 58:594-604

Wagner J, Witt JA, Helmstaedter C, Malter MP, Weber B, Elger CE (2015) Automated volumetry of the mesiotemporal structures in antibody-associated limbic encephalitis. J Neurol Neurosurg Psychiatry 86:735-742. https://doi.org/10.1136/jnnp-2014-307875
Wang D, Hao Q, He L, Wang Q (2018) LGI1 antibody encephalitis and psychosis. Australas Psychiatry 26:612-614. https://doi. org/10.1177/1039856218771513

Warren N, O'Gorman C, McKeon G, Swayne A, Blum S, Siskind D (2019) Psychiatric management of anti-NMDAR encephalitis: a cohort analysis. Psychol Med. https://doi.org/10.1017/S0033 291719003283

Yu Z, Kryzer TJ, Griesmann GE, Kim K, Benarroch EE, Lennon VA (2001) CRMP-5 neuronal autoantibody: marker of lung cancer and thymoma-related autoimmunity. Ann Neurol 49:146-154

Publisher's Note Springer Nature remains neutral with regard to jurisdictional claims in published maps and institutional affiliations. 